\title{
SYNTHESIZING ENVIRONMENTAL AND SOCIO-ECONOMIC SUSTAINABILITY MODELS: A MULTI-LEVEL APPROACH FOR ADVANCING INTEGRATED SUSTAINABILITY RESEARCH AND PRACTICE
}

Mark Starik, Wendy Stubbs, and Suzanne Benn (2016)

Australasian Journal Of Environmental Management Vol. 0 , Iss. 0,0

\begin{abstract}
Over the last decade, increasing research into sustainable business models has produced a number of prototypes that address various dimensions and levels of sustainability. What exists is a patchwork of certification and disconnected frameworks that are less than systematic and comprehensive. This article addresses this lack of integrated, holistic sustainability management research and practice guides by bringing together several salient and strategic sustainability management models. The authors then forward a synthesized, integrated environmental and socio-economic sustainability model that can be used by different types of entities, at different levels of human organization, to identify, apply, assess, evaluate, and improve processes that advance sustainability values. This article concludes by suggesting future directions for modelling and applying the concepts and practices of multiple levels, systems elements, stages, structures, and cultures to advance sustainability management.
\end{abstract}

\section{Keywords:}

corporate sustainability; sustainable business model; theory of sustainability management 


\section{INTRODUCTION}

Numerous attempts have been made to develop conceptual models and practical frameworks for addressing sustainability management, especially at the organizational level (Starik \& Rands, 1995; Gladwin, Kennelly, \& Krause, 1995; Hart, 1995; Bansal \& Roth, 2000; Stead \& Stead, 2004; Dunphy, Griffiths, \& Benn, 2007; Hitchcock \& Willard, 2009; Fisk, 2010; and Arevalo, Castello, de Colle, Lenssen, and Neumann, 2011). Some of these efforts have concentrated either on environmental (Svensson \& Wagner, 2012) or on socioeconomic sustainability, with a few focusing on both types of sustainability (see, for example, Stubbs \& Cocklin, 2008; and Schapke \& Rauschmayer, 2014). A general consensus among both researchers and practitioners appears to be emerging that sustainability management needs to include not only both types of sustainability but that environmental and socioeconomic sustainability concepts and practices also need to be integrated with one another to reflect the evolving perception that the two phenomena are inextricably linked and interactive (Brown, 2011).

While sustainability management models and theories have been forwarded by several researchers in the past, apparently none has gained a recognizable consensus among these researchers and others who might be interested in either or both developments. This lack of consensus may be slowing the progress of the conceptualizing and application of sustainability management and its potential positive impacts.

This article addresses this lack of integrated, holistic sustainability management research and practice by bringing together several salient and strategic sustainability management models which incorporate attention to environmental and socio-economic sustainability. Examples illustrate how each of these models includes both environmental and socio-economic sustainability issues and several management concepts that can help researchers and practitioners focus on key variables within their respective organizations and 
environments. Then, a synthesized, integrated environmental and socio-economic sustainability model is forwarded that can be used by different types of entities, at different levels of human collective activity, to assess and improve processes that advance sustainability management. The article concludes with a set of theoretical and practical implications and limitations, a summary, and an invitation to other researchers to critique, refine, test, and improve the derived model.

\section{Definitions and Perspectives of Sustainability Management}

Numerous authors have identified the significant variability in the usage of the term "sustainability" (see for example, Montiel, 2008). Arguably, this inexactness of the concept is perhaps one of many reasons that humans are not (yet) collectively or individually sustainable (Dimitrov, 2010). In this article, based on research on sustainability definitions (Starik \& Rands, 1995; Garvare \& Johnson, 2015; and Ramsey, 2015) which found that social and environmental aspects, futurity, and limits were common to most descriptions of the term, we define sustainability as: the capability to advance long-term, multi-faceted quality of life.

The methodology employed in this article is conceptual, based on a review of the relevant literature and on the logical connection of concepts of interest in patterns. Our derived, integrated, and combined model was constructed by choosing the most salient aspects of previously advanced models as demonstrated in selected multilevel examples and by logically and consistently integrating those factors into a useful conceptual and practical tool.

Sustainability and Business Models

Current business model structures are largely inherited from the $19^{\text {th }}$ century and are increasingly outmoded in the 21st century (Kelly and White, 2009). Structural inhibitions prevent companies from becoming sustainable (Birkin, et al., 2009b). Examples of companies 
that have adopted new business models do exist. For example, the pharmaceutical company NovoNordisk is publicly traded but owned by a foundation so it can focus on defeating diabetes; Organic Valley, one of the largest organic food companies, is a cooperative owned by farmers; and the largest UK department store group, John Lewis, is owned by its employees with a stated aim of employee happiness (Kelly and White, 2009). Nevertheless, little has changed in business model design to mitigate severe environmental and social issues. To effectively respond to societal, environmental, and business needs of sustainable development, fundamental change is required (Birkin, et al., 2009a, Stubbs and Cocklin, 2008a). Sustainability initiatives within organisations are considered an "add-on" to what remain essentially unsustainable business practices (Markevich, 2009) (for e.g., reducing resource usage and greenhouse gas emissions; recycling to reduce waste; and developing 'green' products). These sustainability initiatives do not involve a radical change to the dominant business model, as they do not incorporate a comprehensive new understanding of the natural, social and economic environments (Birkin, et al., 2009b).

There have been several attempts to define a business model that prioritises sustainability through incorporating a triple bottom line approach to address environmental, social and economic issues (Birkin et al., 2009b). Past research has identified different business model archetypes and sustainable business models that operate in specific industries. For example, Haigh and Hoffman (2014) describe the emergence of "hybrid' models; Short et al (2014) proposed a business model based on industrial symbiosis (networked resource exchanges) in the sugar industry; Lewandowski (2016) designed a circular economy business model; Chopra (2014) investigated an ecopreneurship model; Cohen and Kietzmann (2014) examined shared mobility business models; and, Nair and Paulose (2014) proposed a 'green' business model for the aviation bio-fuel industry. 
Despite these examples, () there is no comprehensive view of how firms can embed sustainability in their business models (Bocken et al., 2014; Boons and Lüdeke-freund, 2013). THE NEED FOR INTEGRATING ENVIRONMENTAL AND SOCIO-ECONOMIC SUSTAINABILITY

\section{Environmental and Socio-Economic Challenges, Crises, and Opportunities}

Relatively few sustainability scholars and practitioners have forwarded both environmental and socio-economic sustainability into integrated management models. These recent attempts may have been only the initial wave of such efforts, since it appears that the increasing complexity of sustainability challenges may mean that the justification for and potential utility of such models are increasing over time. Though often separated for convenience or for focusing on special interests, environmental and socio-economic sustainability phenomena can be seen as co-existing in most human endeavors and to be connected both conceptually and practically (Thomas \& Lamm, 2012; Schapke \& Rauschmayer, 2014). For example, the current major environmental sustainability challenge of climate disruption (Blockstein \& Wiegman, 2010) exists alongside and can be connected to socio-economic sustainability phenomena. The human extraction, production, distribution, and consumption of fossil fuels are responsible for ever-increasing emissions of greenhouse gases causing climate disruption and related growing numbers of human climate-related victims (sometimes called "climate refugees"), including those residing (or formerly residing) on island and in low-lying coastal countries (Biermann \& Boas, 2008). The increase of greenhouse gases to over 400 parts of carbon dioxide per million (NOAA, 2015) has contributed to increases in Arctic and glacial melting, which in turn increases the heatabsorption of surrounding polar bodies of water. This human-induced climate disruption increases sea levels, ocean acidification, and the frequency and severity of storms, flooding, and drought events (IPCC, 2014), which, in turn, are negatively affecting ever-larger numbers 
of humans and their local economies, especially of those who can least afford to adapt to such environmental damage.

Similarly, the major socio-economic sustainability issue or challenge of extreme poverty, exacerbated by ever-widening human economic inequity, exists alongside and can be connected to environmental sustainability phenomena, such as the human susceptibility to diseases related to air, water, and land pollution caused by industrial facilities, often located within or contiguous to their neighborhoods (Evans \& Kantrowitz, 2002). Our human customs, habits, religious beliefs, and general decision dysfunction continue to over-expand the human population by nearly one-and-a-half million net births over deaths each and every week (or about 78 million per year) (Engelman, 2009). Ninety-five percent of the annual increase in population (about 78 million per year) is occurring in developing countries, some of which are already experiencing severe poverty, inequity, and other socio-economic maladies. Each of today's estimated 214,000 additional humans will potentially require additional energy, food, water, and waste management facilities, among many other environmental and socio-economic resources. The human species apparently has yet to devise socio-economic and environmental approaches which can adequately address poverty and inequity, and the related problems of poor health, education, and employment prospects.

Most serious scholars of sustainability recognize the significant interaction between environmental and socio-economic phenomena. For example, the life work of Lester Brown, founder of both sustainability-oriented organizations Worldwatch and the Earth Policy Institute, almost exclusively combined the two topics areas. His World on the Edge tour de force, for example, features chapters on water tables, soil erosion, and climate disruption, as well as "environmental refugees", "failed states”, “eradicating poverty", and "stabilizing population". This approach and many others sometimes trifurcate sustainability into "economic, social, and environmental" (the so-called "triple bottom line"), or for mnemonic 
purposes, "the 3 Ps" (or people, planet, profit) (Fisk, P. 2010). The most obvious conceptual and practical connections among these variables is that humans are involved with them all, being part of and composed of the natural environment (Starik \& Kanashiro, 2013; Garvare \& Johnson, 2015), and, of course, constituting "society" and exchanging value in "economies".

Clearly, if humans are interested in developing systems, societies, economies, and organizational entities (at multiple levels) that promote the capacity for multi-faceted, longterm quality of life, both socio-economic and environmental sustainability need to be addressed, and, if possible, coordinated and integrated with one another and improved over time (Starik \& Kanashiro, 2013; and Asif, Searcy, Zutshi, \& Ahmad, 2011).

Governments, NGOs and businesses worldwide (Girling, 2012) have attempted to address both sets of sustainability challenges, and, the selection of modes to use in addressing these challenges have often involved consideration of the advantages and disadvantages of generalized models versus more specialized approaches. In this article, our focus is on the comprehensive and systematic nature of a combined approach that connects the two types of sustainability management, leading to the suggestion of a framework that synthesizes several integrated environmental and socio-economic sustainability management models.

\section{The Multiple Levels of Human Collective Activity - Micro, Meso, and Macro}

Both academic research and practitioner experience have amply illustrated the concept and reality of multiple levels of human experience and activity, including at least the two of the three main levels of human individuals, organizations, and societies within the general field of management Schapke \& Rauschmayer, 2014; Schneider, Wallenburg, \& Fabel, 2014; Li, 2013; Cavagnaro \& Curiel, 2012). Since "the capability of advancing longterm quality of life" can be identified at multiple levels of human collective activity, in this article, three levels of human sustainability involvement were explored, only one of which is 
a typical "unit of analysis" in sustainability management research (the organizational, or meso, level). The other two levels examined in this article are the sub-organizational (or program/micro) level and the supra-organizational (or network/macro) level. Identifying multiple levels of sustainability management has the potential to surface additional ideas, projects, connections, and alternatives that may have yet to be explored or considered by researchers and practitioners, and their development could contribute to the evolution of sustainability management immersion, a sustainability management theory concept and practice, which has been suggested as a key to sustainability management advancements (Starik \& Kanashiro, 2013). This set of levels, as opposed to just one, also provides a perspective that is reflective of the human collective experience, which occurs at multiple levels and which can influence one another. For example, individual and small sets of leaders, sometimes identified as "champions", can significantly affect the sustainability of the organizations of which they are a part (Andersson \& Bateman, 2000), as can the founders of eco-preneurial and social entrepreneurial startup efforts (Sloan, Klingenberg, \& Rider, 2013). The fields of economics and politics are two of several fields related to sustainability management which have also addressed multiple levels of human collective activity (Ray, 2001). The authors of this article acknowledge, however, that more than 3 levels of human collective activities can be identified and are using the terms "macro, meso, and micro" for illustrative purposes only. In addition, the authors emphasize that those or similar examples could be used to illustrate sustainability management at other levels, as well.

\section{The Interacting Systems of Environmental and Socio-economic Performance}

In addition to conceptualizing and implementing sustainability management at multiple levels to develop ideas, projects, and alternatives for advancing sustainability management (and its immersion throughout our society) developing these multiple levels in practice can lead to a more systems-oriented view of sustainability management. A systems- 
orientation has long been identified as a requisite of sustainability management (Gladwin, Kennelly, \& Krause, 1995; Espinosa \& Porter, 2011; and Svensson \& Wagner, 2012), reinforcing two of our article's themes of sustainability management: comprehensiveness and connectedness. This article's authors conceive that the systems-orientation includes at least three pairs of systems constructs: values/inputs, strategies/processes, and outputs/feedbacks (Starik \& Rands, 1995), while acknowledging that each system is connected to at least one other (Skjeltorp \& Belushkin, 2006). Similarly, one way to identify connections between levels of sustainability management human activities is to link, say, the values/inputs of one level with, say, the outputs/feedbacks of an adjacent level. For instance, the output of a household's recycling or composting effort can become the input of an organizational or community level recycling or composting drop-off/pickup program, and the input of that level potentially sent to a manufacturer using recyclable materials or one processing compostable materials into compost-containing food-growing products. These outputs, in turn, can be recycled into other industries' products and services, often in different sectors and countries (Meinsma, 1996). The more that materials and embodied energy circulate throughout an economy, (Braungart \& McDonough, 2002), the more it can be expected that connections between the values/inputs systems elements of one level can be identified and to trace their connections to the outputs/feedbacks systems elements of another level. The implication here is that the greater the frequency and efficacy of such connections, the more likely those levels and systems can be available to advance sustainability management and its cultural immersion in societies.

\section{EXISTING ENVIRONMENTAL AND SOCIO-ECONOMIC SUSTAINABILITY THEORIES AND MODELS}

While a number of theories and models have been forwarded to help researchers and practitioners try to advance sustainability, including cradle-to-cradle (Braungart \& 
McDonough, 2002), industrial ecology (or symbiosis) (Graedel \& Allenby, 1995), ecological economics (Costanza, Cumberland, Daly, Goodland, \& Norgaard, 1997) and ecological modernization (Milanez \& Buhrs, 2007), very few have focused on both environmental and socio-economic sustainability management and even fewer have focused on the multiple levels of human activity that involve sustainability management (Rands et al., 2007). In this section of the article, three relatively recently-introduced integrated socioeconomic/environmental sustainability models are presented: the Multi-Level, Multi-System Perspective of a Proto-Theory of Sustainability Management, the Sustainability Business Model, and the Sustainability Phase Model. Immediately following each integrated model is an example that highlights each, focusing consecutively on macro (supra-organizational), meso (organizational), and micro (sub-organizational) levels of sustainability management. These particular models were selected for highlighting and synthesizing because each has been forwarded as a way for businesses to envision their organizational environments and to move in more sustainable (both environmentally and socio-economically) directions.

In addition, the several models from which the derived model was constructed were selected because of their apparent complementarity. The Sustainability Phases model accounts for potential changes in organizational environments over time, potentially moving in consistent directions and doing so either incrementally or significantly. As such, it represents one of the first attempts to bring the human, social and environmental elements of sustainability together as a "developmental" model. The other two models (the sustainability business model, and, the multi-level, multi-systems perspective) are more oriented to highlighting the components of both internal and external organizational aspects of sustainability and in describing connections between and among these components, a common feature of comprehensive sustainability practitioner and academic models (Esty \& Winston, 2006; Willard, 2009; Lovins, 2011; Stead \& Stead, 2014). By combining of these 
three models into the "Synthesized, Integrated Environmental and Socio-Economic Sustainability Management Model", the authors derived a combined model which can include sustainability changes over time, with significant detail about both internal and external organizational structure, culture, and systems, at any of three levels, sub-organizational, organizational, and supra-organizational. This model is not only more comprehensive but also more inclusive of the salient aspects of extant sustainability models.

\section{A Multi-Level/Multi-System Perspective of a Proto-Theory of Sustainability}

\section{Management}

One sustainability management model which has integrated both types of sustainability and adopted a multi-level (as well as a multi-systems elements) perspective is the Proto-Theory of Sustainability Management (Starik and Kanashiro, 2013). This "proto" or preliminary theory posited that individuals, organizations, and societies can advance their respective sustainability management efforts (both environmental and socio-economic) if they adopt a systems perspective and if they immerse themselves in the related values, attitudes, and behaviors at the sustainability leading-edge of their respective cultures (see Figure 1).

\section{INSERT FIGURE 1 ABOUT HERE}

Sustainability management immersion means the apparent necessity for human individuals, organizations, and societies to intentionally and systematically surround themselves physically, mentally, and emotionally, with inputs (such as values), processes (such as education), and outputs (such as behaviors) that advance socio-economic and environmental capacities for long-term quality of life. The theory asserts that such 
immersion would increase possibilities for bringing about and a maintaining the continuation of experience and benefit from widespread sustainability results. Sustainability advocates appear to need to encourage human decision-makers to more genuinely consider identifying and developing a wide range of sustainability solutions at multiple levels that would allow many individuals, organizations, and societies to immerse themselves in "all things sustainable". This kind of an approach has been associated with many other human change efforts, including habit alteration, manufacturing quality, foreign language education, cultural sensitivity, technology utilization, athletic skill development, and spiritual and sustainability education (Salz, Serva, \& Heckman, 2013; Maser, 2012; McKenzie-Mohr, 2011; Bodyscott, 2001; Wilkinson, Fogarty, \& Melville, 1996).

Of course, a fully-developed theory of sustainability management would likely include many other aspects of both sustainability and management than those in the "prototheory". Among these inclusions might be phenomena such as those related to time (Bansal \& Knox-Hayes, 2013) and place (Shrivastava \& Kennelly, 2013), various elements of ecosystems (energy, matter, air, water, land, evolution, gravity, cycles, biodiversity, restoration, etc.) (Hawken, et al., 1999), as well as aesthetics, justice, equity, and many other social factors (Sharma, Starik, \& Husted, 2007). While other management theories have been and will continue to be employed in sustainability management research, they will be limited in their usefulness unless they include many of the aspects of a dedicated sustainability management theory. Much the same could be said about sustainability management practices. Unless a phenomenon is a central organizing principle (Gore, 1993) or focus, whether in research or practice, it will probably not receive as much attention as its advocates think it deserves (nor, perhaps, as much as its imperative nature warrants).

The Living Building Challenge Highlighting the Multi-Level/Multi-Systems Perspective (in the Proto Theory of Sustainability Management) at the Macro Level 
A recent exciting development in the global construction industry/sector is the design, implementation, and assessment of the Living Building Challenge (LBC), which is considered, for the purposes of this article, at the supra-organizational (macro level). This is the main offering of the non-profit International Living Futures Institute (ILFI), headquartered in Seattle, WA, with offices in Portland, OR, USA, and in Vancouver, BC, Canada, and is a certification program for builders, architects, and other professionals and building and property owners (and their organizations) interested in advancing the best, most resource-efficient, approach to residential, commercial, institutional, and industrial buildings (ILFI, 2014). The certification is very rigorous, far more so than the better-known LEED (Leadership in Energy and Environmental Design) program. Both the building projects, the applications for which can be submitted by multi-firm consortia, and other professionals in the ILFI network involved can apply for and receive one of several certifications, all of which follow the general process of registration, documentation, operation, audit, and certification. In its latest version (3.0), the certification requires that buildings attain "net positive" levels of energy and water (meaning the necessity to produce more than they consume) and be constructed with non-toxic materials. This version also promotes a number of sustainability goals more prominently: resilience, regeneration, equity, community, materials transparency, and "living future," and increases the amount of attention to both environmental and socioeconomic factors, including ethical considerations, such as aesthetics, equity, and justice regarding employees and communities.

The Living Building Challenge is an example of a supra-organizational entity that integrates environmental and socio-economic values, strategies, and outputs, apparently advancing sustainability management at this level. Projects can be certified as "Living" if they meet all of the program requirements after a year of continued operations and full occupancy. At the time of this writing, more than 100 building projects have been submitted 
by various stakeholders to receive the certification, and, 19 projects/project teams have received one of the three related $\mathrm{LBC}$.

The Living Building Challenge not only includes attention to both environmental and socio-economic sustainability but it also incorporates attention to the multiple levels and systems advanced in the Multi-Level/Multi-Systems Perspective suggested by Starik \& Kanashiro (2013). As mentioned, the LBC can be applied at both the "whole building" level (including restoration) and at the community level. It is also possible to be certified on just a few of the LBC criteria, such as energy or water. While some organizations are multi-faceted enough to apply for and receive the certification alone, many projects require multiple organizations, such as architects, builders, and building and property owners, illustrating the collaboration characteristics of LBC networks. From a systems perspective, LBC projects and ILFI focus attention on the systems elements of values/inputs, strategies/processes, and outputs/feedbacks. The first systems element is amply demonstrated by the LBC inclusion of the values of biophilia, equity, and justice. Among the many other inputs in this program is the accumulation of knowledge from LBC versions 1.0 and 2.0 and from the network of dozens of expert LBC “Ambassadors” or adviser/instructors, and from numerous conferences, workshops, and webinars organized by the ILFI. Regarding strategies/processes, LBC encourages ecological design, construction, utilization, and maintenance of the building projects that are the main features of the LBC applications. Finally, the ILFI is very interested in the project outputs/feedbacks systems elements, demonstrated by its concern for and inclusion of validation of building/property performance (one year after operation/completion) for any of the LBC certifications.

\section{The Sustainability Business Model}

Stubbs and Cocklin (2008a) developed a "sustainability business model" (SBM) that was derived from case studies of two sustainability leaders, Interface, Inc. (Stubbs \& Cocklin, 
2008b) and Bendigo Bank (Stubbs \& Cocklin, 2007). Figure 2 summarises the 'structural' and 'cultural' internal organizational capabilities and external characteristics of the SBM. Structural characteristics are those that relate to processes, organizational forms and structures, and business practices. Cultural characteristics refer to norms, values, behaviours and attitudes (intangible factors).

\section{INSERT FIGURE 2 ABOUT HERE}

Figure 2 highlights that the SBM requires changes in both structural elements and cultural factors. Some characteristics of the SBM can be partially achieved through internal capabilities but also require changes in the external environment, such as implementing closed loop systems. The model reinforces the view that organisations cannot be sustainable until the whole socioeconomic system is sustainable (Gladwin, Kennelly \& Krause, 1995) and suggests the SBM requires long-term structural change in the economy and society.

Table 2 further identifies the characteristics of the SBM. On one dimension, Table 2 groups the characteristics under the headings 'economic', 'environmental', 'social' and 'multi-dimensional or holistic'. The 'multi-dimensional or holistic' column captures those characteristics that have a combination of economic, environmental and social facets or reflect a more holistic approach to sustainability. The second dimension categorizes the characteristics as structural and cultural. However, the SBM takes a systemic perspective which implies integrating the economic, environmental and social aspects of sustainability rather than treating them as self-contained components.

\section{INSERT TABLE 1 ABOUT HERE}


A key finding from Stubbs and Cocklin's (2008a) research into the SBM was that while organisations can make significant progress towards achieving sustainability through their own internal capabilities, ultimately they can only be sustainable when the whole system of which they are part is sustainable (Jennings \& Zandbergen, 1995). An organisation adopting the SBM develops internal structural and cultural capabilities to achieve firm-level sustainability and collaborates with key stakeholders to achieve sustainability for the system of which the organisation is a part.

\section{Australian B Corps Highlighting the Sustainability Business Model (SBM) at the Meso}

\section{Level}

B Corps are for-profit, socially obligated, corporate forms of business with both traditional corporate characteristics and societal commitments (Hiller, 2013). They employ "market tactics to address social and environmental issues" (Hoffman, Badiane \& Haigh, 2012, p133) and epitomise the interweaving of sustainability and strategic management into a business model.

B Corps are certified by B Lab, a non-profit organization founded in 2006 in the USA. To become a B Corp, a business must complete an Impact Assessment, which assesses the overall impact of the company on its stakeholders (a minimum score of 80 out of 200 points is required). In agreeing to the provisions in the B Corp Term Sheet, a B Corp enters into a private contractual agreement to consider broader stakeholder interests than stockholder interests alone. Over 1300 B Corps have been certified by B Lab across 41 counties and 121 industries.

While profits are a key measure of success for the B Corps, they also define success in terms of what the profits allow the businesses to do to make an impact and fulfil their social and environmental purposes (Stubbs, 2014). The B Corps suggest that by making more 
money, they can invest in more activities and projects that could change the world and make a difference (Haigh \& Hoffman, 2012; Stubbs \& Cocklin, 2008a).

B Corps seek to influence others through their advocacy programs. This entails engaging with governments directly and through industry bodies, engaging with companies and clients to keep them improving, and through campaigns and public seminars targeted at raising awareness and changing industry practices. They also lobby government for initiatives to support B Corps, such as tax incentives for investment into social enterprises (Stubbs, 2014).

B Corps are an especially illustrative example of the SBM, highlighting their cultural and structural aspects. Culturally, B Corps treat sustainability as a core component of their business models; their social purpose is their end goal and profits are the means by which they achieve that goal. They manage their organizations for the benefit of their stakeholders (not just shareholders), utilizing their values of stewardship, trust, sharing and collaboration. Structurally, they build multi-stakeholder relationships; use integrated triple bottom line (TBL) reporting; and engage in advocacy, lobbying and education activities to promote systemic changes.

\section{The Sustainability Phase Model}

Scholars have long classified interpretations of sustainability as either strong or weak (Pearce, 1993; Jacobs, 1999), distinguishing between weaker forms of market-based sustainability and the stronger ecosystem-based sustainability (Ayres, van den Berrgh and Gowdy, 2001). The key determining factor is whether all forms of capital, usually designated as social, environmental and economic, are maintained intact independent of one another. When applied to organizational or corporate sustainability, the strong-weak continuum has been addressed through typologies or developmental frameworks. Earlier attempts focus on environmental dimensions of sustainability. Hunt and Auster's (1990) five stage model, for 
example, conceptualised organisations moving from incremental or 'band aid' solutions to fully integrative approaches to corporate greening. Roome (1992) identified five options that business organisations may take up in order to implement environmental responsibility: oncompliance, compliance, compliance plus, commercial and environmental excellence and leading edge. Most attempts at categorisation since have continued to distinguish between reactive and proactive approaches to incorporating environmental considerations with an increasing emphasis on sustainability as an aspect of corporate strategy making. Winn and Angell (2000) for example, expand traditional strategic change models to generate a typology of four types of corporate greening: Deliberate Reactive, Unrealized, Emergent Active, and Deliberate Proactive greening, using case examples to demonstrate the progression.

While phase or stage models have been criticised as over linear given the complexity and diversity of the factors contributing to sustainability performance (Kolk and Mauser, 2002; Schaefer and Harvey, 1998), both practitioners and researchers have continued to apply such typologies in order to usefully compare organisational performance for either environmental or socio-economic sustainability over the past several decades (eg Esty \& Winston, 2006; Hitchcock \& Willard, 2009; Lovins, 2011). A recent trend has been to conflate aspects of corporate social responsibility (CSR) with corporate sustainability (Montiel 2008) and hence such models now include the human or social dimension of sustainability in models describing progression to sustainability (eg Dunphy, Griffiths and Benn, 2007; Benn, Dunphy and Griffiths, 2014; Maon, Lindgreen and Swaen, 2009). Managerial attitudes towards integration of sustainability are similarly categorised such as in Schaltegger et al's (2012, p 103) defensive, accommodative and integrative sustainable business model classifications and in Tulder et al (2014) also characterises managerial attitudes towards sustainability as being either inactive, reactive, active or proactive. 
A well-cited example of this latter approach is the Sustainability Phase Model (Benn et al, 2011; Benn et al, 2014), a revised and updated version of a model originally published in Dunphy, Griffiths and Benn (2003). The model provides a set of six distinct phases which together represent a path that organisations can take in progressing toward sustainability (Table 2). The model represents an early attempt to draw in human resource management and community relations with environmental management (Benn et al, 2006), but has been recently expanded to explain how economic value might be added in each of the phases through implementing sustainability, as set out in Table 2.

\section{INSERT TABLE 2 ABOUT HERE}

The authors emphasise this is an ideal model only and that, in the complex organisations of today, a linear progression towards sustainability is not expected. Trade-offs occur between the social, environmental and economic dimensions of sustainability (AngusLeppan, Benn \&Young, 2010; Hahn et al, 2014), organisations may leapfrog or retreat across phases or their different divisions may move at different rates. However, the model provides a useful tool for identifying and comparing different practices for organizational sustainability within and across organizations.

Table 2 summarises the key features of each phase, setting out the overall objective for each phase; the key business opportunity; typical actions that are taken by organisations to pursue the objective and realise the opportunity and, finally, the sustainability value that can be added for to organisation.

\section{UTS Business School Program Highlighting the Sustainability Phase Model at the}

\section{Micro Level}


How education sector organizations incorporate sustainability into their activities illustrates the importance of examining progress to implementing sustainability at the suborganizational or micro level. In the business school context, for example, analysis of MBA programs using the Sustainability Phase Model suggests that these may vary from a businessas-usual approach (Compliance Phase 3), through a calculative introduction of sustainability according to market demand (Efficiency Phase 4) to a more strategic approach focused on incorporating sustainability into core aspects of the MBA program (Strategic Proactivity Phase 5), while a few business schools have recently attempted to purposely design their MBA programs around sustainability (Rusinko, 2010), and hence can be classified as at the Sustaining Phase 6.

This diversity of sustainability efforts and outcomes at the sub-organizational level is illustrated by applying the Sustainability Phase Model to the example of an undergraduate business school teaching program at UTS Business School, Sydney, Australia, hereafter called the School. The teaching program selected is the undergraduate program Bachelor of Business (BBus), one of the flagship programs of the School. Sustainability is a core theme in this program. In terms of sustainability, the School conducts assurance activities to ensure compliance with Association to Advance Collegiate Schools of Business (AACSB) Standard 9 (requiring that teaching programs at all levels address "Social responsibility, including sustainability, and ethical behaviour and approaches to management.") The AACSB accreditation for the School suggests that the overall BBus teaching program should be placed at least in the Compliance Phase 3.

At the sub-unit level within the BBus, however, the many individual subjects differ as to how they can be placed along the Phase Model. For example, the core subject Integrating Business Perspectives (IBP) IBP acts as a 'reverse capstone' to introduce students to an interdisciplinary understanding of business, specifically designed around the purpose of 
bringing to bear highly coordinated trans-disciplinary understandings on a given 'wicked problem' (Rittel and Webber, 1973), such as food security or climate change. Wicked problems are specifically selected so that they highlight the interconnectedness between the socio-economic and environmental dimensions of sustainability. They become the focus of the student assessments, guest lectures and of the tutorials and the more formal lectures.

Hence, IBP is one subject which appears to approach Phase 6, the Sustaining Organization. This phase is characterized by holistic understandings of sustainability and an emphasis on interconnectedness and restoration - features which accord with the objectives of this particular subject to actively engage students in addressing a major societal problem. Another core subject in the program from the Accounting Discipline falls more within the Efficiency phase - Phase 4. This subject progresses beyond Compliance on the Phase model through its emphasis on Efficiency Phase 4 considerations such as triple bottom line and performance scorecard reporting, the application of quality management principles to environmental reporting, environmental management systems and evaluation of practical difficulties and instrumental benefits of CSR reporting. Various other sustainability subjects within the BBus program remain at Compliance Phase 3.

\section{SYNTHESIZING THREE INTEGRATED ENVIRONMENTAL AND SOCIO- ECONOMIC SUSTAINABILITY MODELS FOR RESEARCH AND PRACTICE}

\section{Conceptually Synthesizing the Three Extant Integrated Sustainability Models}

This article has presented mainly three conceptually-related but distinct sustainability management models and used three different sets of examples, respectively, for illustrating three different levels of sustainability management human activity, which were labelled supra-organizational (or macro), organizational (or meso), and sub-organizational (or micro). 
While each of these models has its strengths, the observation that none incorporates a full range of salient factors indicates that each could be enhanced. That enhancement could take the form of incremental improvements to each, or, alternatively, of the comprehensive development of a combined model to include all of the factors identified earlier in this present article. In this article, the latter approach is advanced, since one of the authors' goals is to help promote the consideration and use of integrated socio-economic and environmental sustainability models in both research and practice.

In this section, the salient aspects of each of these models are combined to provide a more comprehensive and, hopefully, more useful integrated environmental and socio-economic management model. In addition to attention to all three of the generic levels of human activity mentioned above (macro, meso, and micro), which were derived from the ProtoTheory (Multi-Levels/Multi-Systems) of Sustainability Management model, the combined model also includes three stages of sustainability management: beginning/risk management, intermediate/efficiency, and advanced/restorative, from the Sustainability Phases model. Also included in the combined model is a focus on systems elements (from the Proto-Theory of Sustainability Management model) and on two key variable sets from the Sustainable Business Model (SBM) - structure and culture. Collectively, these six features encapsulate a necessary (though perhaps not yet sufficient) set of essential conceptual components of a comprehensive integrated sustainability management model. This synthesized model is illustrated in Table 3, along with our suggestions for possible entries in each of the cells. These suggestions were derived from the extensive examples used to support the three previous models, as well as from the general experience of the authors and several of the multiple academic and practitioner publications that have provided sustainability business suggestions at different stages of the multiple levels of human organized activity. 


\section{INSERT TABLE 3 ABOUT HERE}

\section{An Illustration of the Synthesized, Integrated Sustainability Management Model}

Consider the International Living Futures Institute (ILFI), a non-profit organization based in Portland, Oregon, U.S.A., mentioned earlier in this article regarding the Living Building Challenge (LBC). The ILFI, as a stand-alone non-profit organization which could be considered, for the purposes of this article, as a meso-level entity, has a staff of several dozen professionals organized into several departments or programs (which could be considered the micro level), and an extensive network of members and "ambassador network" of knowledgeable volunteers (which could be considered the macro level), all at least nominally focused on the organization's mission to "work toward a future that is socially just, culturally rich, and ecologically restorative" (ILFI, 2015). The organization operates three certification programs (including the Living Building Challenge already mentioned, the Living Product Challenge, and the Living Community Challenge). Each of these programs include numerous sustainability-based "imperatives", such as "net positive material health", a "red list" of banned (typically toxic) materials and substances, "responsible industry", and "inspiration and education". Sixteen other "petals" (which are not imperative but rather are suggestive) include numerous aspects of building, product, or community aspects related to place, water, energy, health and happiness, materials, equity, and beauty. Given that the ILFI is apparently one of the world's most sustainability-qualified organizations, a strategy to increase the quality or quantity of its sustainability activities would likely begin at the Advanced/Restorative category of stages or phases of the model synthesized in this article. At the organizational or meso level, these could include developing closed loop systems (called net positive waste in the LPC), emphasizing trust and sharing in their internal and external cultures, and advocating with public bodies to reward 
other organizations to implement such changes. The organization already has seeded local chapters or "Collaboratives" in several states in the U.S. Northwest and Canadian province of British Columbia, so expanding that effort to the rest of North America and beyond could be a challenge they could address in the future. If successful, the organization could then move to the supra-organizational or macro level in order to influence (and, hopefully, lead) various industries by participating in industry-wide sustainability networks, becoming sophisticated as a multi-stakeholder event convenor (they currently conduct "Living Future unConferences" and have both in-person and on-line education programs, as well as an online newsletter), and participating in multi-organizational sustainability programs to help those people most vulnerable to negative environmental developments. Such an approach would conform to the its multiple certification "Responsible Industry" imperative which states, in part, that "( $\mathrm{t}$ )he product manufacturer must advocate for the creation and adoption of third-party certified standards for sustainable resource extraction and fair labor practices within its industry," (p. 39). And, of course, much of this response would be based on ensuring that the entities within the ILFI itself, that is, at the micro-level, organizational departments, teams, task forces, committees, and individuals are developing stakeholder networks for sustainability knowledge sharing, collaborating with one another to advance sustainability, and conducting footprint, "handprint", and other impact analyses. So, the ILFI is just one of many organizations that could use the integrated sustainability management model synthesized and presented in this article, at one or more levels, to help advance its sustainability efforts.

\section{Practical and Theoretical Aspects of the Synthesized Model}

The general applicability of this model to practice is that sustainability management champions in nearly any organization could use this framework to initially assess their several sustainability environments, identify connections, and map out a plan for advancing 
sustainability management, either by stage or level or both. Important structural, cultural, and systems-oriented factors can be incorporated into those plans, which could include both current status and future planning perspectives. As was indicated earlier, other similar factors might be either substituted for, or added as complements to, these combined model variables.

Much the same could be said about the combined models' applicability to research. One of the main contributions to sustainability management research is the addition of the concepts of stages of development, structure, and culture to the Proto-Theory of Sustainability Management. That proto-theory has been stated as follows: "(T)he greater the frequency, breadth, depth, genuineness, competency, and systems-orientation of human involvement in addressing sustainability management phenomena at multiple levels, the greater the possibilities for improvements in both the capacities for and achievements of environmental and socio-economic long-term quality of life on a significant scale" (Starik \& Kanashiro, 2013, p17). This and other theories of sustainability management could likely be improved in multiple ways, but the potential strengths of the improvements suggested in this article are that they were developed over an extended period of time by different sets of researchers with different sets of data and perceptions.

For example, the authors of The Sustainability Business Model contributed two important sustainability management variable sets to the development of a sustainability management theory - structure and culture. While their initial explication included variables such as structures, forms, processes, and attitudes, which may be considered internal organizational characteristics, other aspects of that model, such as norms, values, behaviors, and practices may also have elements that are part of or are connected to the broader external contexts (labelled "socio-economic" and "natural" environments in the initial specification of the SBM in Stubbs \& Cocklin, 2008) within which organizations operate. The SBM also acknowledges that internal and external factors at times interact at organizational boundaries 
advancing sustainability efforts and results. These internal and external contexts, and their interaction, can be included in a further specified sustainability management theory, beyond the Proto-Theory mentioned earlier. That aspect is related to the theory's concept of immersion, that is, the frequent, broad, deep, and genuine experience of individuals, organizations, and societies surrounding themselves with cues, information, decisions, actions, and outcomes that can advance sustainability management in multiple ways, both within and outside those entities. The SBM reminds us that "the capacity for long-term multifaceted quality of life", or, sustainability, can, does, and will happen, at least in part, and be advanced within human activities and perceptions, beyond those activities and perceptions, and at the intersection of internal and external contexts.

The Sustainability Phase model contributes the important theoretical idea of sustainability states, stages or approaches that can change over time, highlighting especially differences in the intensity and holistic appreciation of sustainability management activities by development phase. The addition of this concept to sustainability management theory allows the latter to more realistically reflect the fact that human activities vary significantly on sustainability management criteria and that activity profiles are dynamic, subject to ongoing change over time, especially if that change is induced with sustainability intention. Together, these additional models would alter the Proto-Theory of Sustainability Management to also include this statement: "These sustainability management improvements would likely vary by stage of development and include elements of structure and culture, reflecting perceived internal, external, and boundary-interacting phenomena."

\section{CONCLUSIONS AND FUTURE DIRECTIONS}

This article reviewed and extracted concepts from three extant integrated socioeconomic and environmental sustainability management models. For example, B Corps comprised the sample in the development of the Sustainable Business Model. These 
organizations epitomize strategic sustainability, since they are typically new or recent startups whose mission is to advance environmental and/or socio-economic quality of life for multiple stakeholders. In addition, the Living Building Challenge, which is the example used to illustrate the Proto-Theory of Sustainability Management model, became a program of the International Living Building Institute in 2009, in order to establish a strategic leadership position in the green building movement by advocating sustainable building and site development best practices, has recently begun rivalling the long-standing and reputable U.S. Green Building Council's Leadership in Energy and Environmental Design (LEED) building and builder certification programs. Finally, the Sustainability Phase model was illustrated by a number of recent sustainability curricula efforts that could be described as strategically sustainable, since these were conceptually and qualitatively different than traditional business curricula programs, were becoming more central to the entity's mission, and required the strategic characteristics of leadership, innovation, differentiation, and tenacity in meeting educational goals.

\section{Limitations and Related Future Directions}

While the authors believe that the synthesized integrated sustainability management model (and its related impact on improving sustainability management theory) is an improved framework for both sustainability management practice and research, it also exhibits a number of limitations, relating, on the one hand, to its complexity, and, on the other, to the lack of attention to specific cultural and economic contexts. These limitations could be overcome by customising the model to specific varying needs of different researchers and/or practitioners.

Regarding future research on integrated sustainability management models, the limitations point the way toward at least two possible related future research projects. First, other models besides the three that were combined in this article could be connected, 
described, and analyzed, yielding other model factors and suggestions for use. Second, rather than only including the very general contexts of environmental and socio-economic and internal/external/interactive, those contexts which are place-based and focus on specific locations could be included in a combined model which might make the result more usable by different stakeholders.

This article has forwarded the need for a combined environmental and socioeconomic sustainability management model and suggested that three extant sustainability management models could be integrated for use as a comprehensive, rational, and useful framework for both sustainability management practitioners and researchers. It included multiple levels and systems, phases, structure, and cultures as variable categories in that framework and identified several high profile examples in different sectors to illustrate the cells in that framework. It also included one over-arching example (the ILFI) of how the synthesized integrated sustainability management model could be used to advance sustainability efforts at multiple levels of even this sustainability-leading organization. Finally, implications for practitioners and researchers and limitations and future studies were suggested. Rather than an ending, the authors believe and hope this present attempt to develop both sustainability theory and practice is near the beginning of such efforts and encourage this article's readers to critique and refine this article's synthesized model and innovate other frameworks for use by multiple stakeholders to advance sustainability management, as soon and as much as possible.

\section{REFERENCES}

Andersson, L. and Bateman, T. 2000. Individual environmental initiative: Championing natural environmental issues in U.S. business organizations. Academy of Management Journal, 43: 548-570 
Angus-Leppan, T., Benn, S. and Young, L. 2010. A sense-making approach to tradeoffs and ynergies between human and ecological elements of corporate sustainability, Business Strategy and the Environment' 19 (4): 230-244.

Arevalo, J.A., Catello, I., de Colle, S., Lenssen, G., and Neumann, K. 2011. Introduction to the special issue: Integrating sustainability in business models. The Journal of Management Development, 30 (10): 941-954.

Asif, M., Searcy, C., Zutshi, A., and Niaz, A. 2011. An integrated management systems approach to corporate sustainability. European Business Review. 23 (4): 353-367.

Ayres, R., van den Berrgh, J. and Gowdy, J. 2001. Strong versus weak sustainability. Environmental Ethics 23(2): 155-168.

Bansal, P. and Roth, K. 2000. Why companies go green: A model of ecological responsiveness. Academy of Management Journal, 43/4: 717-736.

Bansal, P. and Knox-Hayes, J.K. 2013. The time and space of materiality in organizations and the environment. Organization \& Environment, 26(1): 61-82.

Benn, S., Dunphy, D. and Griffiths, A. 2006. Enabling change for corporate sustainability: An integrated perspective. Australasian Journal of Environmental Management. 13, 35-44

Benn, S., Dunphy, D. and Griffiths, A. 2014. Organizational change for corporate sustainability: A guide for leaders and change agents of the future. $3^{\text {rd }}$ edition. Oxon, UK: Routledge.

Benn, S., Dunphy, D. and Perrott, B. 2011. Cases in corporate sustainability and Change: A Multidisciplinary Approach. Prahan, Australia: Tilde University Press.

Benn, S., Teo, S. and Martin, A. in press. 'Employee participation and engagement in working for the environment', Personnel Review (accepted 31 July 2014). 
Biermann, F. and Boas, I. 2008. 'Protecting climate refugees: The case for a global protocol. Environment'. November-December. 50 (6): 8-17Birkin, F., Cashman, A., Koh, S. and Liu, Z., 2009a. New sustainable business models in China. Business Strategy and the Environment, 18(1), 64-77.

Birkin, F., Polesie, T. and Lewis, L., 2009b. A new business model for sustainable development: an exploratory study using the theory of constraints in Nordic organizations. Business Strategy and the Environment, 18(5), 277-290.

Blockstein, D.E. and Wiegman, L. 2010. The climate solutions consensus: What we know and what to do about it. Washington, D.C.: Island Press.

Bocken, N.M.P., Short, S.W., Rana, P. and Evans, S., 2014. A literature and practice review to develop sustainable business model archetypes. Journal of Cleaner Production, $\mathbf{6 5}(0)$, 42-56.

Bodyscott, P. 2001. Language and cultural immersion: Perspectives on short term study and residence abroad. Hong Kong: Institute for Education.

Bohnsack, R., Pinkse, J. and Kolk, A., 2014. Business models for sustainable technologies: Exploring business model evolution in the case of electric vehicles. Research Policy, 43(2), 284-300.Boons, F. and Lüdeke-Freund, F., 2013. Business models for sustainable innovation: state-of-

the-art and steps towards a research agenda. Journal of Cleaner Production, 45, 9-19. Braungart, M. and McDonough, W. 2002. Cradle to cradle: Remaking the way we make things. New York, NY: North Point Press.

Brenner, S. and Cochrane, P. 1991. The stakeholder theory of the firm: implications for business and society theory and research. IABS Proceedings 1991: 449-467. 
Brown, L.R. 2011. World on the edge: How to prevent environmental and economic collapse. New York: W.W. Norton.

Cavagnaro, E. and Curiel, G. 2012. The three levels of sustainability. Sheffield, UK: Greenleaf Publishing.

Cherrier, H., Russell, S., and Fielding, K. 2012. Corporate environmentalism and top management identity negotiation, Journal of Organizational Change Management, 25 (4): $518-534$

Chopra, K., 2014. Ecopreneurship: Is it a viable business model. AE International Journal of Multidisciplinary Research, 2(3), 1-6.

Cohen, B. and Kietzmann, J. 2014. Ride on! Mobility business models for the sharing economy. Organization \& Environment, 27(3): 279-296.

Costanza, R., Cumberland, J.H., Daly, H.E., Goodland, R., and Norgaard, R. 1997. An introduction to ecological economics. Boca Raton, FL: CRC Press.

Dimitrov, D.K. 2010. The paradox of sustainability definitions. Proceedings of the APIRA Conference. Manuscript 073. July. Sydney, NSW, Australia. http://apira2010.econ.usyd.edu.au/conference_proceedings/APIRA-2010-073-DimitrovThe-paradox-of-sustainability-definitions.pdf accessed 11/09/14

Dunphy, D., Griffiths, A., and Benn, S. 2007. Organizational change for corporate sustainability: A guide for leaders and change agents of the future. $2^{\text {nd }}$ edition. Oxon, UK: Routledge.

Engelman, R. 2009. Population sustainability. Scientific American Earth 3.0. 19 (2): 22-29.

Espinosa, A. and Porter, T. 2011. Sustainability, complexity, and learning: Insights from complex systems approaches. The Learning Organization. 18 (1): 54-72. 
Esty, D.C. and Winston, A.S. 2006. Green to gold: How smart companies use environmental strategy to innovate, create value, and build competitive advantage. New Haven: Yale University Press.

Evans, G.W. and Kantrowitz, E. 2002. Socioeconomic status and health: The potential role of environmental risk exposure. Annual Review of Public Health. 23: 303-331.

Fisk, P. 2010. People, planet, profit: How to embrace sustainability for innovation and business growth. London, GB: Kogan Page Limited.

Freeman, R. E. and Gilbert Jr, D. R. 1992. Business, ethics and society: A critical agenda. Business and Society, 31 (Spring): 9.

Garvare, R. \& Johnson, M. 2015. The crippled bottom line: Measuring and managing sustainability. International Journal of Productivity and Performance Measurement. 64 (3): $334-355$.

Girling, R.H. 2012. The good company. Berkeley, CA, U.S.A.: Hill Press.

Gladwin, T., Kennelly, J., and Krause. 1995. Shifting paradigms for sustainable development: Implications for management theory and research. Academy of Management Review. . 20/4:874-907.

Gore, A. 1992. Earth in the balance: Ecology and the human spirit. New York, NY: Rodale, Inc.

Graedel, T.E. and Allenby, B.R. 1995. Industrial ecology. Upper Saddle River, NJ: PrenticeHall.

Halme, M., Lindeman, S and Linna, P. 2012. Innovation for inclusive business: Intrapreneurial bricolage in multinational corporations. Journal of Management Studies, 49 (4): 743-784 
Handy, C. 2002 What's a business for? Harvard Business Review, 80(12): 49-55.

Hart, S. 1997. Beyond greening: Strategies for a sustainable world. Harvard Business Review. January-February.

Haigh, N. and Hoffman, A.J. 2012. Hybrid organizations: The next chapter of sustainable business. Organizational Dynamics 41 (2): 126-134

Haigh, N. and Hoffman, A.J., 2014. The new heretics: Hybrid organizations and the challenges they present to corporate sustainability. Organization \& Environment, 27(3), 223241.Hawken, P., Lovins, A., and Lovins, L.H. 1999. Natural capitalism: Creating the next industrial revolution. Boston, MA: Little, Brown.

Hiller, J. S. 2013. The benefit corporation and corporate social responsibility. Journal of Business Ethics, 118(2): 287-301.

Hitchcock, D. and Willard, M. 2009. The business guide to sustainability: Practical strategies and tools for organizations. $2^{\text {nd }}$ ed. London, UK: Earthscan.

Hunt, C. and Auster, E.1990. Proactive environmental management: avoiding the toxic trap. MIT Sloan Management Review 31(2): 7-18.

ILFI (International Living Future Institute), 2014. Seattle, WA, U.S.A.: International Living Future Institute.

http://livingfuture.org/sites/default/files/reports/FINAL\%20LBC\%203_0_WebOptimized_ low.pdf Accessed 11/09/14

ILFI (International Living Future Institute), 2015. Seattle, WA, U.S.A.: International Living Future Institute. http://living-future.org/ Accessed 6/12/15

IPCC (Intergovernmental Panel on Climate Change), 2014. Climate change 2014: Impacts, adaptation, and vulnerability. Part A: Global and sectoral aspects. Contribution of 
Working Group II to the Fifth Assessment Report of the Intergovernmental Panel on

Climate Change Cambridge University Press, Cambridge, UK and New York, NY, USA: $1-32$.

Jacobs, M. 1999. Sustainable development as a contested concept. In A. Dobson (ed) Fairness and Futurity: Essays on Environmental Sustainability and Social Justice New York: Oxford University Press. 21-45.

James, C. and Schmitz, C. 2011, Transforming sustainability education: Ethics, leadership, community engagement, and social entrepreneurship, International Journal of Business and Social Science, 2 (5); [Special Issue -March 2011]

Jennings, D. and Zandbergen, P. 1995. Ecologically sustainable organizations: An institutional approach. Academy of Management Review. 20/4: 1015-1052.

Kelly, M. and White, A.L., 2009. From corporate responsibility to corporate design: Rethinking the purpose of the corporation. The Journal of Corporate Citizenship (33), 23-27.

Key, S. 1999. Toward a new theory of the firm: a critique of stakeholder "theory". Management Decision, 37(4): 317-328.

Kolk, A. and Mauser, A. 2002. The evolution of environmental management: from stage models to performance evaluation. Business strategy and the environment 11(1): 14 -31.

Lewandowski, M. 2016. Designing the business models for circular economy-Towards the conceptual framework. Sustainability, 8(1): No. 43 (1-28).

Li, B. 2012. From a micro-macro framework to a micro-meso-macro framework. $n$

Christensen, S.H. (ed.) Engineering, Development, and Philosophy, Dordrecht, NE: Springer. 
Lovins, A.B. 2011. Reinventing fire: Bold business solutions for the new energy era. White River Junction, VT: Chelsea Green Publishing.

Maon, F., Lindgreen, A., and Swaen, V. 2009. Designing and implementing corporate social responsibility: an integrative framework grounded in theory and practice. Journal of Business Ethics. 87:71-89.

Markevich, A. 2009. The evolution of sustainability. MIT Sloan Management Review, 51(1): $13-14$.

Maser, C. 2012. Decision-making for a sustainable environment: A systemic approach. Boca Raton, FL.: Taylor \& Francis.

McKenzie-Mohr, D. 2011. Fostering sustainable behavior. $3^{\text {rd }}$ ed. Gabriola Island, British Columbia, Canada: New Society Publishers.

Meadows, D. H., Meadows, D.L., and Randers, J. 1992. Beyond the limits: Confronting global collapse, envisioning a sustainable future. Post Mills, VT: Chelsea Green Publishing Co.

Meinsma, R.R. 1996. Simulation as an approach to support institutional design. In DeTombe, D.J. \& van Dijkum, C. (eds.) Analyzing complex societal problems: A methodological approach. Munich: Rainer Hampp Verlag. 117-134.

Milanez, B. and Buhrs, T. 2007. Marrying strands of ecological modernization: A proposed framework. Environmental Politics. 16: 565-583.

Montiel, I. 2008. Corporate social responsibility and corporate sustainability: Separate pasts, common futures. Organization \& Environment, 21 (3): 245-269.

Nair, S. and Paulose, H., 2014. Emergence of green business models: The case of algae biofuel for aviation. Energy Policy, 65, 175-184. 
NOAA (National Oceanic and Atmospheric Administration of the U.S. Department of Commerce), 2015. Greenhouse gas benchmark reached. Oceanic and Atmospheric Research. May 6.

Pearce, D. 1993. Blueprint 3: Measuring sustainable development. London: Earthscan. Ramsey, J.L. 2015. On not defining sustainability. Journal of Agricultural and Environmental Ethics. 28 (6): 1075-1087.

Rands, G.P., Ribbens, B.A., Casagrande, D., and McIlvaine-Newsad, H. 2007. Envisioning an ecologically sustainable society: An ideal type and an application. In Sharma, S., Starik, M., \& Husted, B. (eds.) Organizations and the sustainability mosaic: Crafting long-term ecological and societal solutions. Cheltenham, UK: Edward Elgar Publishing. $22-59$.

Ray, J.L. 2001. Integrating levels of analysis in world politics. Journal of Theoretical Politics. 13 (4): 355-388.

Rittel, Horst W. J. and Webber, M. 1973. Dilemmas in a general theory of planning. Policy Sciences 4: 155-169.

Roome, N. 1992. Developing environmental management strategies. Business Strategy and the Environment 1(1): 1-23.

Rusinko, C. A. 2010. Integrating sustainability in management and business education: A matrix approach. Academy of Management Learning \&Education, 9(3): 507-19.

Salz, J., Serva, M., and Heckman, R. 2013. The GET immersion experience: A new model for leveraging the synergies between industry \& academia. Journal of Information Systems Education. 24(2): 121-131.Schapke, N and Rauschmayer, F. 2014. Going beyond efficiency: Including altruistic motives 
in behavioural models for sustainability transitions to address sufficiency. Sustainability: Science, Practice, \& Policy. 10 (1): 29-44.

Schneider, L., Wallenburg, C.M., and Sebastian, F. 2014. Implementing sustainability on a corporate and a functional level: Key contingencies that influence coordination. International Journal of Physical Distribution \& Logistics Management. 44 (6): 464-493.

Sharma, S., Starik, M., and Husted. B. (Eds.) 2007. Organizations and the sustainability mosaic: Crafting long-term ecological and societal solutions. Northhampton, UK: Edward Elgar.

Shrivastava, P. and Kennelly, J. 2013 Sustainability and place-based enterprise. Organization \& Environment. 26: 83-101.

Short, S.W., Bocken, N.M., Barlow, C.Y. and Chertow, M.R., 2014. From refining sugar to growing tomatoes. Journal of Industrial Ecology, 18(5), 603-618.

Skjultorp, A.T. and Belushkin, A.V. 2006. Dynamics of complex interconnected systems: Network and bioprocesses. New York NY: Springer Science + Business Media, LLC

Sloan, K., Klingenberg, B, and Rider, C. 2013. Towards sustainability: Examining the drivers and change process within SMEs. Journal of Management and Sustainability. 3 (2): 19-30.

Starik, M. and Rands, G.P. 1995. Weaving an integrated web: Multilevel and multisystem perspectives of ecologically sustainable organizations. Academy of Management Review. 20(4): 908-935.

Starik, M. and Marcus, A. 2000. Introduction to the special research forum on the management of organizations in the natural environment: A field emerging from multiple paths, with many challenges ahead. Academy of Management Journal. 43/4: 539-546. 
Starik, M. and Kanashiro, P. 2013. Toward a theory of sustainability management:

Uncovering and integrating the nearly obvious. Organization \& Environment. 26 (1): 7 30.

Stead, W.E. and Stead, J. 2003. Sustainable strategic management. Armonk, NY: M.E. Sharpe, Inc.

Stead, J. and Stead, W.E. 2014. Sustainable strategic management, $2^{\text {nd }}$ ed. Sheffield, UK: Greenleaf Publishing.

Stormer, F. 2003. Making the shift: Moving from "ethics pays" to an inter-systems model of business. Journal of Business Ethics, 44(4): 279-289.

Stubbs, W. 2014. Investigation of emerging sustainable business models: The Case of B Corps in Australia. Working paper available at SSRN: http://ssrn.com/abstract=2464758. Accessed 29 July 2014.

Stubbs, W. and Cocklin, C. 2007. Cooperative, community-spirited and commercial: Social sustainability at Bendigo Bank. Corporate Social Responsibility \& Environmental Management, 14: 251-262.

Stubbs, W. and Cocklin, C. 2008a. Conceptualizing a sustainability business model. Organization \& Environment, 21(2): 103-127.

Stubbs, W. and Cocklin, C. 2008b. An ecological modernist interpretation of sustainability: The case of Interface Inc'. Business Strategy and the Environment, 17(8): 512-523.

Svensson, G. \& Wagner, B. 2012. Business sustainability and E-footprints on Earth's life and ecosystems: Generic models. European Business Review. 24 (6): 195-213.

Thomas, T.E. and Lamm, E. 2012. Legitimacy and organizational sustainability. Journal of Business Ethics. 110 (2): 191-203. 
Van Tulder, R., Verbeke, A. and Strange, R. 2014. Taking stock of complexity: In search of new pathways to sustainable development. In R.Tulder, A.Verbeke, and R.Strange (Eds) International business and sustainable development Emerald: Bingley, UK. 1-20.

Wicks, A. C. 1996. Overcoming the separation thesis: The need for a reconsideration of business and society research. Business and Society, 35 (1): 89-118.

Willard, B. 2009. The sustainability champion's guidebook: How to transform your company. Gabriola Island, BC: New Society Publishers

Wilkinson, N., Fogarty, N., and Melvile, D. 1996. Organizational culture change through training and immersion. Journal of Organizational Change Management. 9(4): 69-81.

Winn, M.L, and Angell, L. 2000. Towards a process model of corporate greening. Organization Studies 21(6): 1119-1147.

Zollo, M., Cennamo, C., and Neumann, K. 2013. Beyond what and why: Understanding organizational evolution towards sustainable enterprise models. Organization \& Environment. 26/3: 241-259. 


\section{FIGURE 1}

\section{A Multi-level, Multi-system Perspective of a Proto-Theory of Sustainability}

\section{Management}

Source: Starik, M. \& Kanashiro, P. (2013). Toward a theory of sustainability management:

Uncovering and integrating the nearly obvious. Organization \& Environment. 26 (1): 18.

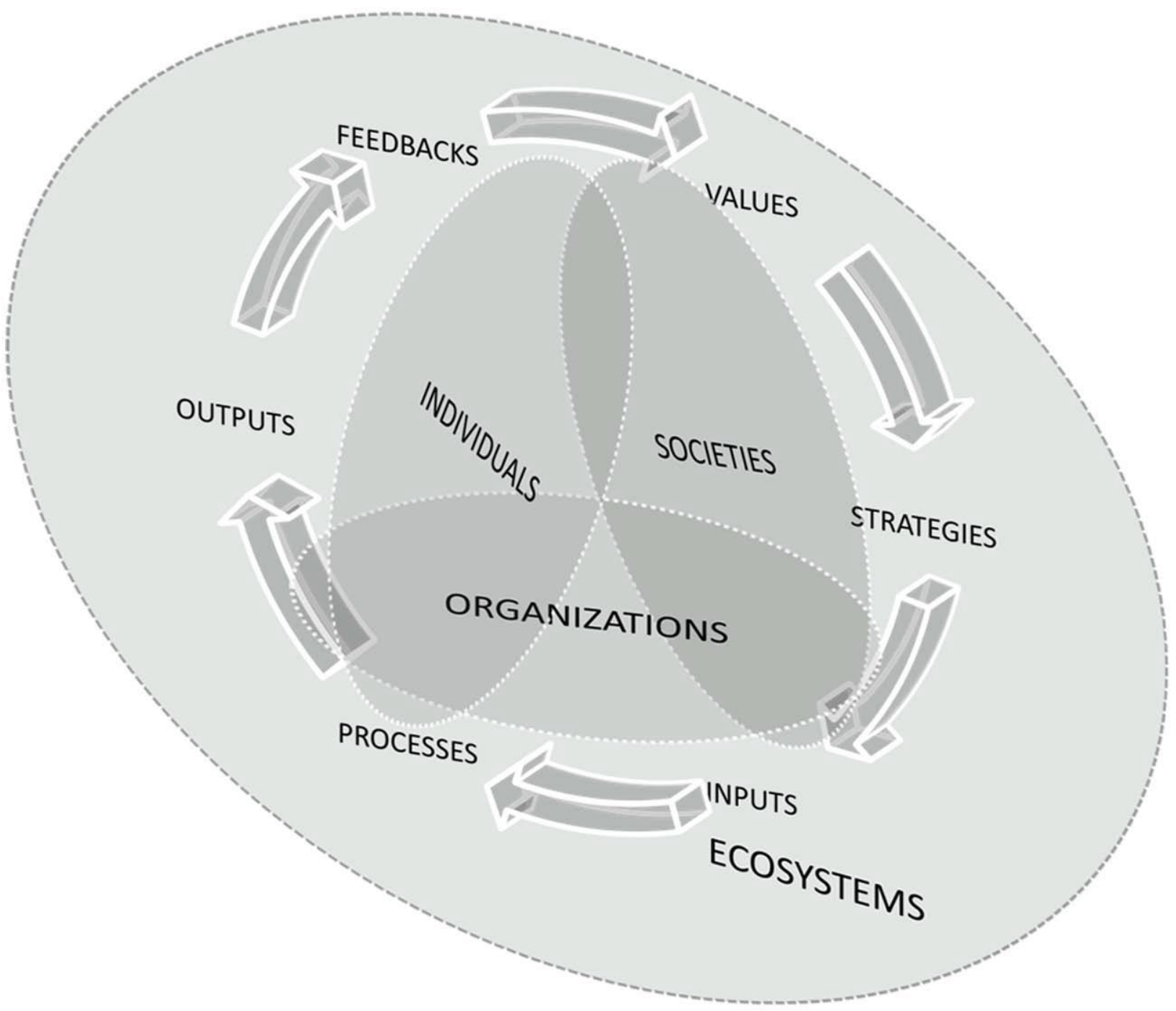




\section{FIGURE 2}

\section{Summary of the characteristics of the Sustainability Business Model}

Adapted from: Stubbs, W. and Cocklin, C. (2008a). Conceptualizing a 'sustainability business model'. Organization \& Environment, 21(2) ): 103-127.

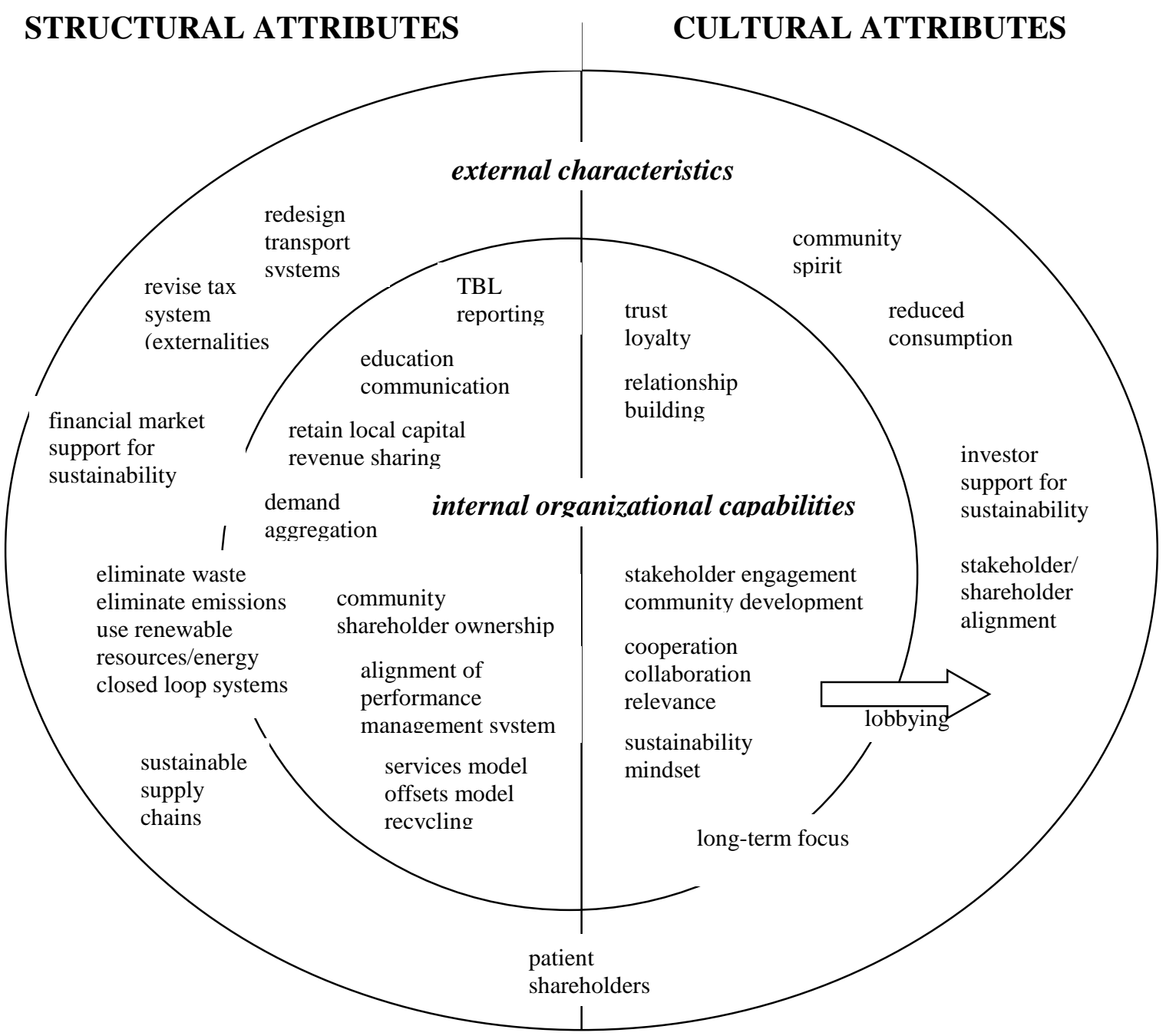


TABLE 1

Characteristics of the Sustainability Business Model

Source: Stubbs, W. and Cocklin, C. (2008a). Conceptualizing a 'sustainability business model'. Organization \& Environment, 21(2) 121.

\begin{tabular}{|c|c|c|c|c|}
\hline & $\begin{array}{l}\text { Economic } \\
\text { characteristics }\end{array}$ & $\begin{array}{l}\text { Environmental } \\
\text { characteristics }\end{array}$ & $\begin{array}{l}\text { Social } \\
\text { characteristics }\end{array}$ & $\begin{array}{l}\text { Multi-dimensional } \\
\text { or holistic } \\
\text { characteristics }\end{array}$ \\
\hline \multirow[t]{3}{*}{$\begin{array}{l}\text { Structural } \\
\text { attributes }\end{array}$} & $\begin{array}{l}\text { External bodies } \\
\text { that track } \\
\text { performance of } \\
\text { companies use a } \\
\text { triple bottom line } \\
\text { (TBL) approach. }\end{array}$ & $\begin{array}{l}\text { Threefold } \\
\text { strategy: Offsets } \\
\text { (do no harm but } \\
\text { make amends if } \\
\text { you do), } \\
\text { sustainable (do } \\
\text { no harm), } \\
\text { restorative } \\
\text { (leave the world } \\
\text { better than you } \\
\text { found it). }\end{array}$ & $\begin{array}{l}\text { Stakeholder } \\
\text { engagement skills: } \\
\text { understanding } \\
\text { stakeholders' needs } \\
\text { and expectations } \\
\text { (being relevant to } \\
\text { stakeholders). }\end{array}$ & $\begin{array}{l}\text { Systems approach: } \\
\text { - Cooperative } \\
\text { business strategy } \\
\text { and planning. } \\
\text { - Collaborative } \\
\text { model including } \\
\text { supply chain, } \\
\text { competitors, } \\
\text { government } \\
\text { agencies, } \\
\text { communities. }\end{array}$ \\
\hline & $\begin{array}{l}\text { Lobby industry } \\
\text { and government } \\
\text { for changes to } \\
\text { taxation system } \\
\text { and legislation to } \\
\text { support } \\
\text { sustainability. }\end{array}$ & $\begin{array}{l}\text { Closed loop } \\
\text { systems: } \\
\text { responsible for } \\
\text { product } \\
\text { throughout its } \\
\text { lifecycle. }\end{array}$ & $\begin{array}{l}\text { Educate } \\
\text { stakeholders; } \\
\text { 'relentless' } \\
\text { communication. }\end{array}$ & $\begin{array}{l}\text { TBL approach to } \\
\text { measure } \\
\text { organizational } \\
\text { performance. }\end{array}$ \\
\hline & $\begin{array}{l}\text { Keep capital local: } \\
\text { local shareholders; } \\
\text { investment in } \\
\text { local sustainability } \\
\text { initiatives. }\end{array}$ & $\begin{array}{l}\text { Implement a } \\
\text { services model. }\end{array}$ & $\begin{array}{l}\text { Implement } \\
\text { stakeholder } \\
\text { consultation } \\
\text { program. }\end{array}$ & $\begin{array}{l}\text { Institutionalise } \\
\text { sustainability in the } \\
\text { business: } \\
\text { 'relentless' } \\
\text { communication; } \\
\text { stakeholder } \\
\text { education; } \\
\text { leadership; } \\
\text { champions; align } \\
\text { internal } \\
\text { performance } \\
\text { measures. }\end{array}$ \\
\hline
\end{tabular}




\begin{tabular}{|c|c|c|c|c|}
\hline & $\begin{array}{l}\text { Economic } \\
\text { characteristics }\end{array}$ & $\begin{array}{l}\text { Environmental } \\
\text { characteristics }\end{array}$ & $\begin{array}{l}\text { Social } \\
\text { characteristics }\end{array}$ & $\begin{array}{l}\text { Multi-dimensional } \\
\text { or holistic } \\
\text { characteristics }\end{array}$ \\
\hline & & $\begin{array}{l}\text { Industrial } \\
\text { ecosystems and } \\
\text { stakeholder } \\
\text { networks. }\end{array}$ & $\begin{array}{l}\text { Get ‘buy-in’ from } \\
\text { internal and external } \\
\text { stakeholders. }\end{array}$ & $\begin{array}{l}\text { Demand-driven } \\
\text { model not supply- } \\
\text { driven model } \\
\text { (driven by what } \\
\text { people need not } \\
\text { driven by companies } \\
\text { trying to get people } \\
\text { to buy more). }\end{array}$ \\
\hline \multirow[t]{4}{*}{$\begin{array}{l}\text { Cultural } \\
\text { attributes }\end{array}$} & $\begin{array}{l}\text { Profit is a means } \\
\text { not an ends. } \\
\text { Business makes a } \\
\text { profit to do } \\
\text { something more. } \\
\text { 'Higher purpose' } \\
\text { to business than } \\
\text { making money. }\end{array}$ & \multirow[t]{4}{*}{$\begin{array}{l}\text { Treat nature as a } \\
\text { stakeholder. } \\
\text { Environmental } \\
\text { stewardship. }\end{array}$} & $\begin{array}{l}\text { Stakeholder } \\
\text { approach (managing } \\
\text { the organisation for } \\
\text { the benefit of all } \\
\text { stakeholders and not } \\
\text { prioritising } \\
\text { shareholders' } \\
\text { expectations above } \\
\text { other stakeholders'). }\end{array}$ & $\begin{array}{l}\text { Medium to long } \\
\text { term focus. }\end{array}$ \\
\hline & $\begin{array}{l}\text { Shareholders } \\
\text { invest for social \& } \\
\text { environmental } \\
\text { impact reasons as } \\
\text { well as for } \\
\text { financial reasons. }\end{array}$ & & $\begin{array}{l}\text { Alignment of } \\
\text { stakeholder } \\
\text { expectations. }\end{array}$ & \multirow[t]{3}{*}{$\begin{array}{l}\text { Reduction in } \\
\text { consumption }\end{array}$} \\
\hline & $\begin{array}{l}\text { Shareholders } \\
\text { temper } \\
\text { expectations for } \\
\text { short-term } \\
\text { financial returns. }\end{array}$ & & $\begin{array}{l}\text { Sharing of resources } \\
\text { (people, profits, } \\
\text { time) amongst } \\
\text { stakeholders to } \\
\text { achieve sustainable } \\
\text { outcomes. }\end{array}$ & \\
\hline & & & $\begin{array}{l}\text { Relationship } \\
\text { building (trust, two- } \\
\text { way loyalty, } \\
\text { honesty, integrity, } \\
\text { fairness, equity). }\end{array}$ & \\
\hline
\end{tabular}

TABLE 2

The Sustainability Phase Model 
Adapted from: Benn, S., Dunphy, D. \& Griffiths, A. (2014). Organizational change for

corporate sustainability: A guide for leaders and change agents of the future. $3^{\text {rd }}$ edition.

Oxon, UK: Routledge.

\begin{tabular}{|c|c|c|c|}
\hline \multicolumn{4}{|c|}{ Phase 1 Rejection: } \\
\hline Key objective & Business opportunity & Actions & Source of value \\
\hline \multirow[t]{2}{*}{$\begin{array}{l}\text { Economic } \\
\text { profit - short } \\
\text { term focus }\end{array}$} & $\begin{array}{l}\text { Employees can be used } \\
\text { as sources of profit }\end{array}$ & $\begin{array}{l}\text { Resist community/ } \\
\text { government claims to } \\
\text { restrain activities }\end{array}$ & $\begin{array}{l}\text { Exploitation of natural/ } \\
\text { human capital }\end{array}$ \\
\hline & $\begin{array}{l}\text { Natural environment } \\
\text { seen as a free resource }\end{array}$ & $\begin{array}{l}\text { Active externalising } \\
\text { environmental/ OHS costs }\end{array}$ & Short term profits \\
\hline \multicolumn{4}{|c|}{ Phase 2 Non-responsiveness: } \\
\hline \multirow[t]{2}{*}{$\begin{array}{l}\text { Business as } \\
\text { usual }\end{array}$} & Compliant workforce & $\begin{array}{l}\text { Externalising } \\
\text { environmental/ OHS costs }\end{array}$ & $\begin{array}{l}\text { Short term operations } \\
\text { and results }\end{array}$ \\
\hline & $\begin{array}{l}\text { Low profile with } \\
\text { community }\end{array}$ & $\begin{array}{l}\text { Disregard of community } \\
\text { concerns unless pressured }\end{array}$ & \\
\hline \multicolumn{4}{|c|}{ Phase 3 Compliance: } \\
\hline \multirow[t]{3}{*}{ Avoid risk } & $\begin{array}{l}\text { Reducing costs of } \\
\text { sanctions }\end{array}$ & $\begin{array}{l}\text { Determining relevant } \\
\text { regulations and community } \\
\text { expectations }\end{array}$ & $\begin{array}{l}\text { Improved relations with } \\
\text { stakeholders }\end{array}$ \\
\hline & $\begin{array}{l}\text { Effective risk } \\
\text { management system }\end{array}$ & $\begin{array}{l}\text { Implementation of } \\
\text { measuring and monitoring } \\
\text { systems }\end{array}$ & Easier access to finance \\
\hline & $\begin{array}{l}\text { Acceptance by } \\
\text { community }\end{array}$ & $\begin{array}{l}\text { Accordance with supply } \\
\text { chain codes of conduct }\end{array}$ & $\begin{array}{l}\text { Stable relations with } \\
\text { employees }\end{array}$ \\
\hline \multicolumn{4}{|c|}{ Phase 4 Efficiency: } \\
\hline \multirow[t]{4}{*}{$\begin{array}{l}\text { Do more with } \\
\text { less }\end{array}$} & $\begin{array}{l}\text { Increase efficiencies by } \\
\text { waste reduction and } \\
\text { reorganisation }\end{array}$ & $\begin{array}{l}\text { Redesign products to } \\
\text { enable remanufacturing/ } \\
\text { add social value }\end{array}$ & Cost reduction \\
\hline & & $\begin{array}{l}\text { Meet GRI Reporting } \\
\text { Guidelines }\end{array}$ & $\begin{array}{l}\text { Increase employee } \\
\text { productivity }\end{array}$ \\
\hline & & $\begin{array}{l}\text { Reduce resource use } \\
\text { according to circular } \\
\text { economy principles }\end{array}$ & $\begin{array}{l}\text { Increase employee } \\
\text { engagement }\end{array}$ \\
\hline & & $\begin{array}{l}\text { Support team-based and } \\
\text { process efficiencies }\end{array}$ & $\begin{array}{l}\text { Focus on teamwork and } \\
\text { collaboration to prompt } \\
\text { innovation }\end{array}$ \\
\hline \multicolumn{4}{|c|}{ Phase 5 Strategic Proactivity: } \\
\hline $\begin{array}{l}\text { Lead in value } \\
\text { adding and }\end{array}$ & $\begin{array}{l}\text { Become market leader } \\
\text { by pursuing strategic }\end{array}$ & $\begin{array}{l}\text { Be early in new product } \\
\text { service demand curves }\end{array}$ & Employer of choice \\
\hline
\end{tabular}




\begin{tabular}{|c|c|c|c|}
\hline \multirow[t]{4}{*}{ innovation } & $\begin{array}{l}\text { potential in } \\
\text { sustainability }\end{array}$ & & \\
\hline & & $\begin{array}{l}\text { Increase employee } \\
\text { engagement to source } \\
\text { innovative ideas }\end{array}$ & $\begin{array}{l}\text { Operate at higher value } \\
\text { end of market }\end{array}$ \\
\hline & & $\begin{array}{l}\text { Implement new models of } \\
\text { stakeholder governance }\end{array}$ & $\begin{array}{l}\text { Lead in developing new } \\
\text { markets }\end{array}$ \\
\hline & & $\begin{array}{l}\text { Creatively destroy existing } \\
\text { business approaches to } \\
\text { leapfrog competition }\end{array}$ & $\begin{array}{l}\text { Stronger stakeholder } \\
\text { support, including across } \\
\text { supply networks }\end{array}$ \\
\hline \multicolumn{4}{|c|}{ Phase 6 The Sustaining Organisation: } \\
\hline \multirow[t]{5}{*}{$\begin{array}{l}\text { Create a } \\
\text { sustainable } \\
\text { world }\end{array}$} & $\begin{array}{l}\text { Systemic approach to } \\
\text { redefining business } \\
\text { around sustainability }\end{array}$ & $\begin{array}{l}\text { Create a constructive culture } \\
\text { where employees thrive and } \\
\text { engage in open debate }\end{array}$ & $\begin{array}{l}\text { Global leadership in the } \\
\text { sustainability movement }\end{array}$ \\
\hline & & $\begin{array}{l}\text { Reorganise supply networks } \\
\text { around sustainable outcomes }\end{array}$ & $\begin{array}{l}\text { Enhanced reputation and } \\
\text { stakeholder support }\end{array}$ \\
\hline & & $\begin{array}{l}\text { Work proactively with } \\
\text { partners towards restoring } \\
\text { natural and social capital, } \\
\text { alleviate poverty }\end{array}$ & $\begin{array}{l}\text { Attraction of talented, } \\
\text { highly motivated } \\
\text { employees }\end{array}$ \\
\hline & & $\begin{array}{l}\text { Influence capital markets to } \\
\text { support long term value- } \\
\text { adding }\end{array}$ & $\begin{array}{l}\text { Knowledge sharing in } \\
\text { collaborative } \\
\text { arrangements around } \\
\text { sustainability }\end{array}$ \\
\hline & & $\begin{array}{l}\text { External auditing of socio- } \\
\text { economic and environmental } \\
\text { performance }\end{array}$ & $\begin{array}{l}\text { Indepth product/ service } \\
\text { knowledge }\end{array}$ \\
\hline
\end{tabular}


TABLE 3

Potential Characteristics of A Synthesized, Integrated Environmental and Socio-

Economic Sustainability Management Model

\begin{tabular}{|c|c|c|c|c|c|c|c|}
\hline Stages & \multicolumn{3}{|c|}{ Beginning/Risk Avoidance } & \multicolumn{3}{|c|}{ Intermediate/Efficiency } & \\
\hline Imperatives & Structure & Culture & Systems & Structure & Culture & Systems & Stru \\
\hline $\begin{array}{l}\text { MICRO } \\
\text { LEVEL } \\
\text { Combined } \\
\text { Environmental } \\
\text { \& Social } \\
\text { Sustainability } \\
\text { Examples }\end{array}$ & $\begin{array}{l}\text { Micro } \\
\text { sustainability } \\
\text { policies, plans, } \\
\text { linked to meso } \\
\text { level }\end{array}$ & $\begin{array}{l}\text { Compliance to } \\
\text { legislation } \\
\text { codes of } \\
\text { conduct }\end{array}$ & $\begin{array}{l}\text { Risk profiling } \\
\text { at product/ } \\
\text { program/ } \\
\text { process/ unit } \\
\text { level }\end{array}$ & $\begin{array}{l}\text { Unit/ program/ } \\
\text { department } \\
\text { sustainability } \\
\text { performance } \\
\text { assessment } \\
\text { systems }\end{array}$ & $\begin{array}{l}\text { Cost benefit } \\
\text { analysis of } \\
\text { innovations in } \\
\text { key products/ } \\
\text { processes }\end{array}$ & $\begin{array}{l}\text { Units/ } \\
\text { programs } \\
\text { identify } \\
\text { circular } \\
\text { economy } \\
\text { constraints/ } \\
\text { opportunities }\end{array}$ & $\begin{array}{l}\text { Decen } \\
\text { stakeh } \\
\text { networ } \\
\text { interpl } \\
\text { betwer } \\
\text { champ } \\
\text { senior } \\
\text { manag }\end{array}$ \\
\hline $\begin{array}{l}\text { MESO } \\
\text { LEVEL } \\
\text { Combined } \\
\text { Environmental } \\
\text { \& Social } \\
\text { Sustainability } \\
\text { Examples }\end{array}$ & $\begin{array}{l}\text { Sustainability } \\
\text { officer and } \\
\text { other specific } \\
\text { roles/ } \\
\text { responsibilities }\end{array}$ & $\begin{array}{l}\text { Sustainability } \\
\text { included in } \\
\text { employee } \\
\text { feedback/ } \\
\text { consultation } \\
\text { processes }\end{array}$ & $\begin{array}{l}\text { Government } \\
\text { and NGO } \\
\text { relationships } \\
\text { fostered }\end{array}$ & $\begin{array}{l}\text { Integrated and } \\
\text { TBL reporting } \\
\text { and assurance }\end{array}$ & $\begin{array}{l}\text { Employee } \\
\text { empowerment } \\
\text { and } \\
\text { engagement; } \\
\text { Emphasis on } \\
\text { productivity }\end{array}$ & $\begin{array}{l}\text { Meso/ macro } \\
\text { system } \\
\text { alignment e.g. } \\
\text { with suppliers }\end{array}$ & $\begin{array}{l}\text { Closed } \\
\text { networ } \\
\text { relatio } \\
\text { Netwo } \\
\text { flexibl } \\
\text { corpor } \\
\text { structu }\end{array}$ \\
\hline $\begin{array}{l}\text { MACRO } \\
\text { LEVEL } \\
\text { Combined } \\
\text { Environmental } \\
\text { \& Social } \\
\text { Sustainability } \\
\text { Examples }\end{array}$ & $\begin{array}{l}\text { Provide energy } \\
\text { audits/ reports } \\
\text { including for } \\
\text { low income } \\
\text { residents }\end{array}$ & $\begin{array}{l}\text { Provide } \\
\text { adequate } \\
\text { working } \\
\text { conditions for } \\
\text { employees } \\
\text { throughout } \\
\text { value chain }\end{array}$ & $\begin{array}{l}\text { Develop and } \\
\text { offer } \\
\text { community } \\
\text { education } \\
\text { sustainability } \\
\text { program }\end{array}$ & $\begin{array}{l}\text { Sharing } \\
\text { economy } \\
\text { principles } \\
\text { incorporated } \\
\text { into } \\
\text { partnerships/ } \\
\text { industry sector } \\
\text { collaborations }\end{array}$ & $\begin{array}{l}\text { Focus on } \\
\text { multi-sector, } \\
\text { multi- } \\
\text { organizational } \\
\text { resource } \\
\text { management }\end{array}$ & $\begin{array}{l}\text { Participate in } \\
\text { community } \\
\text { recycling, food } \\
\text { wastage and } \\
\text { related } \\
\text { sustainability } \\
\text { programs }\end{array}$ & $\begin{array}{l}\text { Partici } \\
\text { climat } \\
\text { global } \\
\text { networ }\end{array}$ \\
\hline
\end{tabular}


